\title{
Nutritive value of green forage and crop by-products of Cynara cardunculus
}

\author{
Cecilia Cajarville ${ }^{\mathrm{a} 1}$, Javier González ${ }^{\mathrm{a} *}$, Jose Luis Repetto ${ }^{\mathrm{a} 1}$, \\ Carlos Alberto Rodríguez ${ }^{\mathrm{a}}$, Adela Martínez ${ }^{\mathrm{b}}$
}

\footnotetext{
a Departamento de Producción Animal, Escuela Técnica Superior de Ingenieros Agrómonos Universidad Politécnica de Madrid, Ciudad Universitaria, 28040 Madrid, Spain

${ }^{\text {b }}$ Centro de Investigación Aplicada y Tecnología Agraria de Villaviciosa, Villaviciosa, Spain
}

(Received 16 February 1999; accepted 15 July 1999)

\begin{abstract}
The nutritive value of cardoon (Cynara cardunculus L.) green forage (GF), dry leaves (DL) and straw (S) was studied from chemical composition analyses and from voluntary intake, digestibility and rumen degradability estimations obtained using adult wethers. Aptitude for being ensiled according to the wilting period was also evaluated making silages with fresh forage and after 24 and 94 hours of wilting. Green forage had a high nutritive value, as shown by low levels of fibre and lignin and its very high digestibility ( $86 \%$ for $\mathrm{OM})$. Nevertheless, its voluntary intake was relatively low $\left(64 \mathrm{~g} \mathrm{DM} \cdot \mathrm{kg}^{-1} \mathrm{LW}^{0.75}\right)$, although very variable among animals. Fermentation characteristics of the GF silages were good and wilting reduced silage losses and improved the quality of silages. Nutritive value of DL was high, but limited only by a moderate crude protein content. Supplemented with urea, it had an OM digestibility similar to a medium-good quality hay $(65.9 \%$ average) and a voluntary intake equivalent to a good quality grass $\left(75.9 \mathrm{~g} \mathrm{DM} \cdot \mathrm{kg}^{-1} \mathrm{LW}^{0.75}\right)$. Finally, $\mathrm{S}$ was a typical fibrous and low protein forage, but when supplemented with urea, it had an intake and a digestibility higher than those of cereal straws. Variations in digestibility for OM and energy among the different non-preserved Cynara cardunculus forages showed close relationships with fibre fractions, especially with the acid detergent lignin content." (@ Elsevier/Inra).
\end{abstract}

\section{Cardoon / degradability / digestibility / intake / silage}

Résumé - Valeur nutritive du fourrage vert et des sous-produits de culture de Cynara cardunculus. La valeur nutritive du fourrage vert, des feuilles sèches et de « la paille » de Cardon (Cynara cardunculus L.) a été étudiée à partir des analyses de composition chimique, et des estimations de digestibilité, de dégradabilité et d'ingestion volontaire chez le mouton. La valeur énergétique des

\footnotetext{
* Correspondence and reprints

Tel.: (34) 91 5493069; fax: (34) 91 5499763; jgonzalez@pan.etsia.upm.es

${ }^{1}$ Present address: Departamento de Nutrición Animal, Facultad de Veterinaria, Universidad de la República Oriental del Uruguay, Lasplaces 1550, Montevideo, Uruguay
} 
fourrages a également été déterminée ainsi que l'aptitude du fourrage vert à être ensilé (soit directement, soit après 24 et $94 \mathrm{~h}$ de préfanage). La valeur nutritive du fourrage vert à été élevée en relation avec ses faibles teneurs en parois cellulaires et en lignine, et sa forte digestibilité ( $86 \%$ pour la matière organique $(\mathrm{MO}))$. En revanche, son ingestion volontaire a été relativement faible $\left(64 \mathrm{~g} \mathrm{de} \mathrm{MS} \cdot \mathrm{kg}^{-1} \mathrm{P}^{0,75}\right)$, et très variable entre les animaux. Malgré un pouvoir tampon élevé, le fourrage s'est très bien ensilé grâce à sa teneur élevée en glucides solubles. Les caractéristiques fermentaires des ensilages ont été bonnes, le préfanage entraînant une diminution importante des pertes totales et une augmentation de la qualité de l'ensilage. Les feuilles sèches ont eu une valeur nutritive élevée mais une teneur en matières azotées modérée. Complémentées avec de l'urée, elles ont eu une digestibilité de la MO (valeur moyenne $=65.9 \%$ ) similaire à celle d'un foin de moyenne ou de bonne qualité et une ingestibilité égale à celle d'une bonne herbe de pâturage (75.9 g de MS $\left.\mathrm{kg}^{-1} \mathrm{P}^{0,75}\right)$. La paille, fourrage riche en parois cellulaires et pauvre en matières azotées, complémentée avec de l'urée a eu une digestibilité et une ingestibilité très supérieure à celles des pailles de céréales. Pour la MO et l'énergie, les variations des valeurs de digestibilité entre les différents fourrages de Cynara cardunculus ont été reliées aux fractions des parois cellulaires, et plus particuliérement à la teneur en lignine. Celles des digestibilités des parois cellulaires et de la lignocellulose ont été principalement liées aux teneurs en parois. (C) Elsevier/Inra).

\section{cardon / dégradabilité / digestibilité / ingestion volontaire / ensilage}

\section{INTRODUCTION}

The cardoon (Cynara cardunculus L.), a perennial herbaceous species, is a kind of thistle that belongs to the same genus as the artichoke and grows naturally in Mediterranean countries, where the petioles of its lower leaves have been traditionally used for human food. During the first natural cycle of the plant, a rosette of leaves develops in winter and the stalk begins to elongate in spring. In early summer, a corym type is produced at the top of the stalk with capitules that contain the seeds. During summer, the aerial part of the plant becomes dry, leaving underground buds in a latent stage. At the beginning of autumn, leaves sprout from the stump, beginning a new cycle which can be repeated over an eight year period $[7,8]$.

This plant is well adapted to semi-arid conditions with high bio-mass production per ha. According to previous studies [8,9], when the cycle is completed in summer, about 20 to $30 \mathrm{t} \cdot \mathrm{ha}^{-1}$ of dry matter (DM) can be obtained and also 2 to $3 \mathrm{t} \cdot \mathrm{ha}^{-1}$ of seeds with high contents of proteins and lipids. As a consequence, industrial possibilities for this crop are being studied, such as the use of the bio-mass for energy production or in the paper industry, and the extraction of oil from the seeds $[8,9]$. Up till now, cardoon is of low agronomic importance, but its use for ruminants could be considered. For this reason, it would be interesting to study the nutritive value for ruminants of different products derived from this crop.

According to Fernández et al. [9], 5 to $7 \mathrm{t} \mathrm{DM} \cdot \mathrm{ha}^{-1}$ of green forage can be produced in autumn and winter, when forage resources are scarce in the south of Europe. Romero et al. [25] estimated higher values (from 8.2 to $9.6 \mathrm{t} \mathrm{DM} \cdot \mathrm{ha}^{-1}$ ) during a period of three years. The use of green forage as animal feed at this moment is compatible with the industrial uses of final biomass, as root reserves support the development of new leaves during winter and spring, allowing the plant to complete its cycle, even with a decrease in the final biomass production $[8,9]$. In addition, several by-products can be used as feeds for livestock. These are the aerial bio-mass resulting from seed harvest, a lignocellulosic material which includes mainly stalks (called straw in this work), and the basal leaves that remain on the field after harvest because they are under the sward level. 
The information concerning the nutritive value of materials from Cynara cardunculus is very limited. Therefore, the aim of the present work was to investigate the nutritive value of green forage, straw and dry basal leaves of Cynara cardunculus, studying their chemical composition and their digestibility, and also to evaluate the potential of green forage to be ensiled in relation with the degree of wilting.

\section{MATERIALS AND METHODS}

\subsection{Forages}

Green forage (GF): this material is composed of the leaves of the rosette developed in winter (vegetative stage). The forage for this work was obtained from experimental crops located at Madrid (Spain), cutting the plants approximately $5 \mathrm{~cm}$ above the ground. Two harvests were made: GF1 (December, 1994, $5.7 \mathrm{t} \mathrm{DM} \cdot \mathrm{ha}^{-1}$ ) used for nutritive value evaluations, and GF2 (February, 1996, $5 \mathrm{t} \mathrm{DM} \cdot \mathrm{ha}^{-1}$ ) used only for ensiling trials.

Dry leaves (DL): these are the basal leaves that remain on the field after dry biomass harvest. This material had the same origin as GF and was obtained by manual raking, so it contained a considerable amount of soil contamination. Forage from two harvests was obtained: DL1 (August, 1994) and DL2 (August, 1995).

Straw (S): this forage is the crop residue of the seed harvest and included mainly stalks, and also stem-leaves and capitula residues. It was obtained in August 1994 from a commercial crop (province of Seville, Spain).

All these forages were analysed for their chemical composition and were used in voluntary intake, digestibility, degradability and rate of passage through the digestive tract trials.

\subsection{Chemical composition}

Chemical composition analysis included dry matter (DM), organic matter (OM), crude protein $(\mathrm{CP})$, ether extract (EE), crude fibre (CF) [3], neutral detergent fibre (NDF), acid detergent fibre (ADF), and acid detergent lignin (ADL) [24]. Also, neutral detergent insoluble nitrogen (NDIN) and acid detergent insoluble nitrogen (ADIN) were obtained by Kjeldahl anal- ysis on NDF and ADF residues, respectively. NDIN and ADIN contents were expressed as \% of total nitrogen. Fibre fractions were calculated as ash-free. Ash contents of NDF and ADF fractions were determined burning the respective residues at $550^{\circ} \mathrm{C}$. GF was dehydrated by lyophilisation to perform chemical composition analysis.

\subsection{Voluntary intake and digestibility}

These measurements were carried out on six adult wethers (four in the case of GF1) of the Manchega breed. Animals were fed the evaluated forage ad libitum, and allowed for $10 \%$ feed refusal $(25 \%$ in the case of DL, because of the soil contamination). Dry leaves and straw were respectively supplemented with 1 and $2.5 \%$ (in DM) of urea in solution, which was sprayed daily. All the trials were carried out during winter and consisted in an adaptation period of 15 days followed by 10 days of intake measure. In the last seven days of this period, faeces were collected to determine digestibility of dry matter (DMD), organic matter (OMD), crude protein (CPD), neutral detergent fibre (NDFD), acid detergent fibre (ADFD) and gross energy (GED). Energy value of the forages was determined as gross energy (GE) and digestible energy (DE) by measuring heat production from the offered forage, refusals and faeces in an adiabatic calorimeter bomb. Metabolisable energy (ME) and net energy expressed as feed units (UFL and UFV) were estimated following the Inra procedure [33]

\subsection{Ruminal degradability and passage rate}

These studies were performed on GF1, DL1 and $\mathrm{S}$ samples using three rumen cannulated wethers. They were fed at an intake level of $40 \mathrm{~g}$ $\mathrm{DM} \cdot \mathrm{kg}^{-1} \mathrm{LW}^{0.75}$, in two equal meals per day, with a diet composed (on DM) of $66.6 \%$ Cynara cardunculus forages $(33.3 \% \mathrm{GF} 1,22.2 \% \mathrm{DL} 1$ and $11.1 \% \mathrm{~S}$ ) and $33.4 \%$ commercial concentrate. The CP content of this ration was $121 \mathrm{~g} \cdot \mathrm{kg}^{-1}$ (on DM). Forages were incubated in nylon bags (ref. 120 T, Tissages Tissues Techniques, France, $46 \mu \mathrm{m}$ pore size), of $11 \times 7 \mathrm{~cm}$ (inner dimensions) made by heat-sealing and filled with approximately $3 \mathrm{~g}$ of feed samples (air dry basis). Previously, GF1 was dehydrated by lyophilisation and all the forages were ground to pass a $2 \mathrm{~mm}$ screen. The bags were incubated in the rumen 
of each wether at times of $2,4,8,16,24,48$ and 72 hours for GF1 and 3, 6, 12, 24, 48, 72 and $96 \mathrm{~h}$ for DL 1 and S. Two replications were performed for each incubation time in different days. After collecting bags from the rumen they were washed with tap water and stored frozen. Once thawed for analysis, bags were washed three times for 5 minutes in a turbine washing machine, dried at $80^{\circ} \mathrm{C}$ for $48 \mathrm{~h}$, and analysed for DM and $\mathrm{OM}$ and also for nitrogen for GF1. Additionally, three bags of each feed were reserved for zero incubation, which involved the washing procedure without prior rumen incubation. Degradation characteristics of $\mathrm{OM}$ and nitrogen were described using the model proposed by Ørskov and McDonald [18], $d=a+b\left(1-\mathrm{e}^{-k d t}\right)$ where $d(\%)$ is disappearance at time $t, a(\%)$ is the soluble fraction, $b(\%)$ is the potentially degradable fraction and $k d\left(\mathrm{~h}^{-1}\right)$ is the fractional rate of degradation of fraction $b$. Ruminal undegradable fraction $(u ; \%)$ was calculated as $100-(a+b)$. Ruminal effective degradability $(D ; \%)$ was estimated as $a+(b \times k d /(k d+k p))$ according to the rate of passage through the rumen $\left(k p ; \mathrm{h}^{-1}\right)$ obtained for each forage.

To obtain $k p$ values determinations were carried out in 2 trials, using as markers Eu (DL1) and $\mathrm{Yb}(\mathrm{S})$ in trial 1 and $\mathrm{Eu}(\mathrm{GF} 1)$ in trial 2. Previously, forages were washed at $90{ }^{\circ} \mathrm{C}$ with sodium lauryl sulphate and dried in an air forced oven $\left(70^{\circ} \mathrm{C}\right)$. Then, they were marked by immersion for $24 \mathrm{~h}$ in acid solutions of $\mathrm{YbCl}_{3}$ or $\mathrm{EuCl}_{3}$, using a concentration of $5 \mathrm{mg}$ of rare earth $\mathrm{g}^{-1}$ of dry residue. The technique was performed according to the recommendations of Ellis and Beever [6] and had been described by González et al. [10]. Each forage was offered to the animals in a single dose $(40 \mathrm{~g})$ and samples were collected in faeces. Collection of faeces was made through a period of 154 hours post-doses in trial 1 and 145 hours in trial 2. A resting period of seven days was introduced between both trials. The samples collected were ashed at $550^{\circ} \mathrm{C}$ and digested by boiling with a solution of $1.5 \mathrm{M}$ $\mathrm{HNO}_{3}$ and $\mathrm{KCl}\left(3.81 \mathrm{~g} \cdot \mathrm{L}^{-1}\right)$. Concentration of markers in the solutions was analysed for $\mathrm{Yb}$ by atomic absorption spectrometry $(\lambda=398.8 \mathrm{~nm})$ and for Eu by atomic emission spectrometry $(\lambda=459.4 \mathrm{~nm})$, using pre-dosed samples of faeces to prepare common-matrix standards. The evolution of the concentration of the marker in faeces according to the time was established for each animal using the model proposed by Dhanoa et al. [5] and mean retention time in the digestive tract (MRT) was calculated as: $k 1^{-1}+k 2^{-1}+T$. In accord with these authors, the smallest rate constant $\left(k l ; \mathrm{h}^{-1}\right)$ was assumed as the rumen out- flow rate $(k p)$, whereas $k 2\left(\mathrm{~h}^{-1}\right)$ represents probably the caecal outflow rate and $T$ the retention time in the remainder digestive compartments.

\subsection{Ensiling trials}

All the forage (GF2) was cut the same day and nine silages were made immediately or after 24 and 94 hours wilting on the field, using three replicates per treatment. For silage making, forage was chopped at $5-10 \mathrm{~cm}$ and then introduced and pressed into $30 \mathrm{I}$ drums provided with an effluent drainpipe. Before ensiling, the forage of each treatment was analysed for DM, water-soluble carbohydrates (WSC) [14], buffering capacity [19] and OM enzymatic digestibility (EDOM) [23]. After 60 days, silos were opened and silages were analysed for $\mathrm{pH}, \mathrm{DM}, \mathrm{OM}, \mathrm{CP}, \mathrm{NDF}, \mathrm{CF}$, EDOM, soluble nitrogen ( $\mathrm{N}-\mathrm{Kjeldahl}$ on pressure extracted juice), ammonia nitrogen (colorimetry on pressure extracted juice using the Merck test, ref. 1.14752), WSC, and acetic, propionic, butyric and lactic acids (gas chromatography: Perkin Elmer 8500, Carbopack $80 / 120$ column).

\subsection{Statistical analysis}

All the data were analysed using the statistical package SAS version 6.08 (SAS Institute Inc., North Carolina, USA). The different kinetics associated with the indicated models (ruminal degradability and passage rate) were fitted to a non-linear regression [22], using the DUD method of the NLIN procedure of SAS software [26]. Comparison of ruminal degradation parameters of OM among forages were performed by analyses of variance considering animals as blocks and the means were compared by protected LSD test. Comparisons of OM and N degradation parameters of GF1 were made by the paired $t$-test. Differences among forages for the digestive transit parameters $(k 1, k 2, T$ and MRT) were studied by variance analyses and orthogonal contrasts, also considering animal effects. The stepwise regression method was used to predict digestibility of the studied forages from chemical composition. Effects of length of wilting periods on silage fermentation parameters were studied by variance analyses and orthogonal contrasts. In addition, linear and quadratic regressions were used to fit fermentation parameters to the length of the wilting period. 


\section{RESULTS}

\subsection{Chemical composition, voluntary intake and digestibility}

Table I shows chemical composition of GF, DL and S samples. The chemical composition of GF reflects a high quality. This material had a high proportion of cellular contents $\left(749 \mathrm{~g} \cdot \mathrm{kg}^{-1}\right.$ DM on average for GF1 and GF2, calculated as 1000 - NDF), an acceptable CP content $\left(144 \mathrm{~g} \cdot \mathrm{kg}^{-1} \mathrm{DM}\right.$ as average of GF1 and GF2) and low levels of fibre (NDF and ADF), especially lignin, because more than $55 \%$ of ADL is represented by cutin. The development of the vegetative cycle involves important variations in the chemical composition of this material. So, DL samples show higher contents of fibre (CF, NDF and ADF) and ADL than GF samples, without an evident variation of the cutin content. In addition, DL samples show lower contents of $\mathrm{CP}$, associated with an important increase of the NDIN and especially ADIN proportions. For both forages, differences in the chemical composition between samples obtained in different harvests are probably a consequence of different climatic conditions. The chemical composition of $\mathrm{S}$ is typical of a fibrous and low protein forage.
Green forage and especially DL presented low contents of OM, with considerable variation between samples of different years. This could be due to a high soil contamination of these materials, as consequence of the contact of the basal leaves with the ground surface. According to Van Soest et al. [29], ash contents in NDF and ADF fractions are respectively good estimations of contamination silica and total silica (biogenic + contamination) contents in forages. In this work, total silica was high for GF and DL (ash content in ADF was $4.6 \%$ for GF1 and $11.2 \%$ for DL1, on dry basis) mainly corresponding to contamination of silica (ash content in NDF was $4 \%$ for GF1 and $9.0 \%$ for DL1, on dry basis). However, silica content was low in $\mathrm{S}(1.2 \%$ ash in ADF and $1.0 \%$ in NDF, on dry basis), which is probably related to the erect nature of the latter material.

Voluntary intake, digestibility coefficients and energy values for GF1, DL (DL1 and DL2 average) and S are presented in table II. Intake of GF1 was lower than the value obtained for the same material after the maturation process (DL samples), although it was very variable among wethers. GF1 presented very high digestibility coefficients for all the analysed fractions.

Table I. Chemical composition ( $\mathrm{g} \cdot \mathrm{kg}^{-1} \mathrm{DM}$ ) of Cynara cardunculus green forage (GF1, GF2), dry leaves (DL1, DL2) and straw (S) samples.

\begin{tabular}{lccccc}
\hline & GF1 & GF2 & DL1 & DL2 & S \\
\hline Dry matter (\%) & 12.3 & 13.8 & 92.4 & 90.6 & 92.2 \\
Organic matter & 812 & 850 & 762 & 729 & 866 \\
Crude protein & 156 & 132 & 65.7 & 91.1 & 72.0 \\
Ether extract & 28.1 & 14.0 & 35.1 & 28.0 & 14.3 \\
Crude fibre & 124 & 134 & 252 & 268 & 341 \\
Neutral detergent fibre & 239 & 264 & 397 & 419 & 607 \\
Acid detergent fibre & 162 & 165 & 295 & 306 & 438 \\
Acid detergent lignin & 26.0 & 34.5 & 64.8 & 70.2 & 69.1 \\
Cutin & 15.5 & 19.3 & 18.7 & 18.5 & \\
Neutral detergent insoluble $\mathrm{N}^{1}$ & 6.83 & & 24.4 & 29.7 & 18.1 \\
Acid detergent insoluble $\mathrm{N}^{1}$ & 2.28 & & 20.4 & 24.4 & 18.0 \\
\hline
\end{tabular}

${ }^{1}$ As $\%$ of total $\mathrm{N}$. 
The DMD of DL was low, even lower than that of S. However, the OMD of DL was higher, which should be in relation to the soil contamination of the material. The DMD and OMD of DL were influenced by the year of harvest. So, DMD of DL1 $(56.6 \%)$ was higher than DL2 $(50.9 \%)$ (SEM $=0.42, P=0.003$ ). The same occurred with OMD, which was $68.6 \%$ for DLl and $63.2 \%$ for DL2 (SEM $=0.41, P=0.003$ ). These differences are in agreement with the chemical composition of the two samples, presenting DL2 higher contents in fibre (NDF and ADF) and lignin. Nevertheless, this sample had more $C P$, even though NDIN and ADIN percentages were also higher. The CPD values of DL are biased by the urea supplementation. Assuming that urea digestibility is $100 \%$, CPD values for DL are nearer $35-45 \%$ for these two samples. The CPD values of $S$ were also distorted by urea supplementation. If urea digestibility is assumed to be $100 \%$, the $\mathrm{CPD}$ of $\mathrm{S}$ could be near $58 \%$. Differences between DL and S for urea corrected CPD are in agreement with the differences of
NDIN and ADIN proportions in these byproducts.

Gross energy of GFI was lower than the usual values for forages because of its high ash content. In spite of this, and mainly as a consequence of its high digestibility, the net energy content resulted quite high. Energy values of DL were strongly affected by the high soil contamination of the material, and appeared quite low. Variation between years was important. Net energy contents of DL1 $(\mathrm{UFL}=0.74 \pm 0.12, \mathrm{UFV}=0.70 \pm 0.14)$ were higher than DL2 $(\mathrm{UFL}=0.61 \pm 0.03$, $\mathrm{UFV}=0.55 \pm 0.04)$, in agreement with higher values in OMD and gross energy of DLI.

Table III shows the best predictions found for digestibility values from chemical components of the studied forages. Crude protein digestibility was not analysed because assays for DL and S were performed with urea supplementation. Good predictions of the digestibility of global fractions (OM and energy) can be obtained from ADL or ADF contents. Nevertheless, the use of this last

Table II. Mean values and standard deviation of voluntary intake $\left(\mathrm{g} \cdot \mathrm{kg}^{-1} \mathrm{LW}^{0.75}\right)$, digestibility $(\%)$, and energy concentration of green forage (GF1), dry leaves (DL) and straw (S).

\begin{tabular}{|c|c|c|c|}
\hline & GF1 & $\mathrm{DL}^{1}$ & $S$ \\
\hline Voluntary intake & $64.0( \pm 22.8)$ & $75.9( \pm 14.5)$ & $44.0( \pm 7.5)$ \\
\hline \multicolumn{4}{|l|}{ Digestibility } \\
\hline Dry matter & $78.3( \pm 1.5)$ & $53.7( \pm 3.2)$ & $56.4( \pm 4.3)$ \\
\hline Organic matter & $86.1( \pm 1.3)$ & $65.9( \pm 3.1)$ & $57.7( \pm 4.2)$ \\
\hline Energy & $82.7( \pm 1.6)$ & $59.9( \pm 3.3)$ & $52.8( \pm 5.1)$ \\
\hline Crude protein & $77.6( \pm 3.0)$ & $58.0( \pm 2.4)$ & $80.9( \pm 2.0)$ \\
\hline Neutral detergent fibre & $78.9( \pm 0.7)$ & $66.9( \pm 2.6)$ & $50.6( \pm 4.4)$ \\
\hline Acid detergent fibre & $80.3( \pm 0.6)$ & $69.2( \pm 2.6)$ & $51.5( \pm 4.4)$ \\
\hline \multicolumn{4}{|l|}{ Energy concentration } \\
\hline Gross energy $^{2}$ & 15.90 & 14.60 & 16.24 \\
\hline Digestible energy ${ }^{2}$ & $13.19( \pm 0.30)$ & $9.62( \pm 1.27)$ & $8.57( \pm 0.99)$ \\
\hline Metabolisable energy ${ }^{2}$ & $11.00( \pm 0.11)$ & $7.90( \pm 1.08)$ & $6.89( \pm 0.83)$ \\
\hline $\mathrm{UFL}^{3}$ & $0.97( \pm 0.01)$ & $0.66( \pm 0.11)$ & $0.55( \pm 0.08)$ \\
\hline $\mathrm{UFV}^{3}$ & $0.96( \pm 0.02)$ & $0.61( \pm 0.13)$ & $0.46( \pm 0.08)$ \\
\hline
\end{tabular}

I average value for DL1 and DL2 samples. ${ }^{2} \mathrm{MJ} \cdot \mathrm{kg}^{-1} \mathrm{DM} .{ }^{3}$ per $\mathrm{kg}$ DM. 
Table III. Regression equations for digestibility of Cynara cardunculus forages in function of chemical components $(n=16)$.

\begin{tabular}{lccc}
\hline Equation & RSD & $\mathrm{R}^{2}$ & $\mathrm{P}$ \\
\hline OMD $=99.55( \pm 3.29)-1.00( \pm 0.10) \mathrm{ADF}$ & 4.2 & 0.881 & $<0.001$ \\
OMD $=101.26( \pm 3.54)-5.80( \pm 0.59) \mathrm{ADL}$ & 4.3 & 0.875 & $<0.001$ \\
GED $=98.82( \pm 3.67)-6.22( \pm 0.61) \mathrm{ADL}$ & 4.5 & 0.883 & $<0.001$ \\
GED $=95.93( \pm 4.15)-1.04( \pm 0.12) \mathrm{ADF}$ & 5.3 & 0.834 & $<0.001$ \\
GED $=102.36( \pm 3.22)-1.05( \pm 0.08) \mathrm{ADF}-0.40( \pm 0.10) \mathrm{NDIN}$ & 3.6 & 0.929 & $<0.001$ \\
NDFD $=97.37( \pm 2.61)-0.76( \pm 0.06) \mathrm{NDF}$ & 3.3 & 0.929 & $<0.001$ \\
ADFD $=99.78( \pm 2.73)-0.78( \pm 0.06) \mathrm{NDF}$ & 3.4 & 0.927 & $<0.001$ \\
\hline
\end{tabular}

RSD, residual standard deviation; OMD, organic matter digestibility; GED, gross energy digestibility; NDFD, neutral detergent fibre digestibility; ADFD, acid detergent fibre digestibility; ADF, acid detergent fibre; ADL, acid detergent lignin; NDIN, neutral detergent insoluble nitrogen; NDF, neutral detergent fibre. NDF, ADF and ADL are expressed as \% on DM and NDIN as \% of total N.

Table IV. Mean values of excretion kinetic parameters $(k l, k 2, T)$ and mean retention time (MRT) for Cynara cardunculus green forage and by products.

\begin{tabular}{lcccc}
\hline & $k l\left(\% \cdot \mathrm{h}^{-1}\right)$ & $k 2\left(\% \cdot \mathrm{h}^{-1}\right)$ & $T(\mathrm{~h})$ & MRT (h) \\
\hline GF & 2.85 & 12.9 & 25.1 & 70.0 \\
DL & 2.56 & 13.2 & 22.3 & 70.2 \\
S & 1.95 & 11.4 & 22.2 & 84.6 \\
SEM & 0.14 & 0.66 & 0.30 & 2.02 \\
Contrast (P) & & & & \\
$\quad$ GF v. (DL+S) & 0.026 & 0.995 & 0.002 & 0.031 \\
$\quad$ DL v. S & 0.037 & 0.264 & 0.882 & 0.005 \\
\hline
\end{tabular}

GF, green forage; DL, dry leaves; S, straw.

parameter for GED allows a better prediction, with the introduction of the NDIN proportion as a second independent variable. On the contrary, the digestibility of fibre fractions (NDF or ADF) was basically determined by the fibre content of these forages.

\subsection{Rate of passage through the digestive tract and ruminal degradability}

Table $I V$ presents the kinetic parameters of marker faecal excretion $(k 1, k 2$ and $T)$ and mean retention time (MRT) in the digestive tract of GF1, DL1 and S. The $k 1$ value of GF1 was higher than the average of byproducts. Between these, DL1 had a higher value than $\mathrm{S}$. On the other hand, no differences were observed for $\mathrm{k} 2$ values and only a higher $T$ value was observed for GF1 in relation with by-products.

Table $V$ shows the comparison of $\mathrm{OM}$ degradation kinetics between forages. Organic matter degradation of GF1 is characterised by a high degradability $(79.9 \%)$ and a low undegradable fraction $(6.6 \%)$. Degradation kinetics and effective degradability of nitrogen of GF1 was almost identical to that of the OM, without any difference between parameters. Thus, the soluble and rapidly degradable (a), potentially degradable (b) and undegradable (u) fractions showed values of $45.9,47.4$ and 
Table V. Mean values for organic matter degradation kinetic parameters $(a, b, k d)$, undegradable fraction $(u)$ and effective degradability $(D)$ of Cynara cardunculus green forage and by-products.

\begin{tabular}{lccccc}
\hline & $\begin{array}{c}a \\
(\%)\end{array}$ & $\begin{array}{c}b \\
(\%)\end{array}$ & $\begin{array}{c}k d \\
\left(\% \cdot \mathrm{h}^{-1}\right)\end{array}$ & $\begin{array}{c}u \\
(\%)\end{array}$ & $\begin{array}{c}D \\
(\%)\end{array}$ \\
\hline GF1 & $46.6^{\mathrm{a}}$ & $46.8^{\mathrm{b}}$ & $7.52^{\mathrm{a}}$ & $6.60^{\mathrm{c}}$ & $79.9^{\mathrm{a}}$ \\
DL1 & $12.8^{\mathrm{b}}$ & $74.9^{\mathrm{a}}$ & $2.97^{\mathrm{b}}$ & $12.3^{\mathrm{b}}$ & $53.3^{\mathrm{b}}$ \\
$\mathrm{S}$ & $12.2^{\mathrm{b}}$ & $38.6^{\mathrm{c}}$ & $3.26^{\mathrm{b}}$ & $49.1^{\mathrm{a}}$ & $36.2^{\mathrm{c}}$ \\
SEM & 0.47 & 1.37 & 0.84 & 1.41 & 0.96 \\
$\mathrm{P}$ & $<0.001$ & $<0.001$ & 0.032 & $<0.001$ & $<0.001$ \\
\hline
\end{tabular}

a-c Means within columns that do not share a common superscript differ $(P<0.05)$.

$6.7 \%$, respectively, with respective SED values (paired t test) in relation to $\mathrm{OM}$ degradation values (table $V$ ) of $0.99,0.95$ and 0.26 . The fractional rate of $\mathrm{N}$ degradation $(\mathrm{kd})$ was of $7.77 \% \cdot \mathrm{h}^{-1}(\mathrm{SED}=0.30)$. Nitrogen effective degradability $(79.7 \%)$ was similar to that of OM $(\mathrm{SED}=0.7 \mathrm{l})$. As expected, maturation of the leaves and development of the stems resulted in important decreases of effective degradability of these materials. Effective degradability of OM in DLl was considerably lower than in GF1, as a consequence of an increase of the undegradable fraction and an important reduction of the soluble fraction as well as the fractional degradation rate. Meanwhile, degradability of $S$ was characteristic of a poor forage, with a high proportion of undegradable components and low proportions of soluble and degradable components and, as a result, a poor OM effective degradability.

\subsection{Green forage silage}

Table VI shows initial composition of Cynara cardunculus green forage (GF2) according to wilting period and the main parameters of resulting silages. This forage presents high values of buffering capacity, moisture and WSC. In addition, this forage was easy to compact, as shown the high initial densities of the silages, which increase $(P=0.008)$ with wilting of the material.
Values of EDOM obtained for GF2 are in agreement with the in vivo digestibility of OM observed for GF1 sample. All the silages had $\mathrm{pH}$ levels lower than 4.5 , imperceptible contents of butyric acid, high levels of lactic acid - that were 3 to 5 times higher than those of acetic acid - and ammonia contents lower than $0.3 \%$ (on DM). The final parameters of silages showed some variations according to wilting period. Concentration of fibre (NDF and CF) was lower for wilted silages. Total losses were high for the fresh forage silage $(19.8 \%$ of the weight), but decreased according the wilting period until $4.6 \%$ for silages with $94 \mathrm{~h}$ wilting. The increase of the wilting period produced a linear increase of $\mathrm{pH}\left(\mathrm{R}^{2}=0.82\right.$, $P<0.001)$ and a linear decrease of lactic acid concentration $\left(\mathrm{R}^{2}=0.60, P=0.014\right)$. This increase also produced a decrease of ammonia concentration and, in contrast, an increase in propionic acid, but this is of small quantitative importance.

\section{DISCUSSION}

\subsection{Chemical composition, voluntary intake and digestibility}

The chemical composition obtained for GF is similar to that reported by Romero et al. [25], except for NDF, ADF, and ADL values $\left(384,251\right.$ and $93 \mathrm{~g} \cdot \mathrm{kg}^{-1} \mathrm{DM}$, respectively). Also, results reported by Fernández 
Table VI. Initial and final characteristics and composition of Cynara cardunculus green forage silages with different periods of wilting.

\begin{tabular}{|c|c|c|c|c|c|c|}
\hline \multirow[t]{2}{*}{ Wilting (h): } & \multirow[t]{2}{*}{0} & \multirow[t]{2}{*}{24} & \multirow[t]{2}{*}{94} & \multirow[t]{2}{*}{ SEM } & \multicolumn{2}{|c|}{ Contrast $(\mathrm{P})$} \\
\hline & & & & & 1 & 2 \\
\hline \multicolumn{7}{|l|}{ Initial forage } \\
\hline Dry matter ( \%) & 13.8 & 15.7 & 22.7 & & & \\
\hline Water soluble carbohydrates 1 & 270 & 283 & 270 & & & \\
\hline Buffering capacity ${ }^{2}$ & 70.1 & 58.3 & 63.5 & & & \\
\hline $\operatorname{EDOM}(\%)$ & 87.5 & 88.6 & 88.8 & & & \\
\hline \multicolumn{7}{|l|}{ Silage parameters } \\
\hline Initial density $\left(\mathrm{kg} \cdot \mathrm{L}^{-1}\right)$ & 0.81 & 0.88 & 0.89 & 0.01 & 0.008 & 0.557 \\
\hline Total looses $(\%)$ & 19.8 & 12.0 & 4.60 & 1.06 & $<0.001$ & 0.003 \\
\hline $\mathrm{pH}$ & 4.03 & 4.10 & 4.28 & 0.03 & 0.011 & 0.010 \\
\hline Dry matter $(\%)$ & 15.0 & 17.1 & 21.8 & 0.42 & $<0.001$ & $<0.001$ \\
\hline Organic matter $^{1}$ & 836 & 834 & 832 & 1.65 & 0.194 & 0.388 \\
\hline Crude protein ${ }^{1}$ & 136 & 137 & 133 & 4.48 & 0.899 & 0.581 \\
\hline Neutral detergent fibre ${ }^{1}$ & 281 & 255 & 240 & 6.74 & 0.007 & 0.159 \\
\hline Crude fibre $^{1}$ & 147 & 137 & 129 & 3.23 & 0.011 & 0.127 \\
\hline Water soluble carbohydrates 1 & 141 & 159 & 140 & 10.5 & 0.551 & 0.235 \\
\hline EDOM $(\%)$ & 84.8 & 87.9 & 89.7 & 1.13 & 0.026 & 0.320 \\
\hline Soluble nitrogen ${ }^{1}$ & 10.6 & 10.6 & 9.23 & 0.84 & 0.547 & 0.290 \\
\hline Ammonia $^{1}$ & 2.66 & 2.53 & 1.91 & 0.13 & 0.035 & 0.018 \\
\hline Acetic acid ${ }^{1}$ & 31.2 & 34.6 & 31.2 & 2.70 & 0.614 & 0.406 \\
\hline Propionic acid ${ }^{1}$ & 0.08 & 0.16 & 0.17 & 0.02 & 0.024 & 0.693 \\
\hline Butyric acid & $\operatorname{tr}$ & tr & $\operatorname{tr}$ & & & \\
\hline Lactic acid ${ }^{1}$ & 167 & 124 & 91.2 & 14.9 & 0.018 & 0.168 \\
\hline
\end{tabular}

${ }^{1} \mathrm{~g} \cdot \mathrm{kg}^{-1} \mathrm{DM} ;{ }^{2} \mathrm{meq} \cdot 100 \mathrm{~g}^{-1} \mathrm{DM}$. EDOM enzymatic digestibility of organic matter. Contrast $1: 0 \mathrm{v} .(24+94) ;$ 2: 24 v. 94 .

et al. [9] showed higher contents in cell wall components of GF $\left(362,285\right.$ and $143 \mathrm{~g} \cdot \mathrm{kg}^{-1}$ $\mathrm{DM}$ for NDF, ADF and ADL, respectively). This disagreement is probably due to the existence of chemical interference in the determination of sequential fibre fractions (NDF, ADF and ADL) when a 'Fibertec' apparatus is used. So, using this kind of apparatus in the present assay, the NDF residue for GF and DL presented a hard agglomeration, like a stone, and this prevented $\mathrm{ADF}$ reagent and sulphuric acid to act. Therefore, estimates of fibrous fractions are overvalued using this methodology and resulting ADL values (129 $\mathrm{g} \cdot \mathrm{kg}^{-1} \mathrm{DM}$ for GF1) are not consistent with the digestibility results. The use of bohemia glasses for these samples avoids this error, allowing shaking the contents and crumbling the residue during the rinse, obtaining the results presented in table $I$.

Digestibility values obtained for GF1 are in agreement with the high degradability observed for this forage (table $V$ ) and are similar to those obtained by Romero et al. [25] $(\mathrm{OMD}=85.1 \%, \mathrm{CPD}=75.7 \%)$, which also show a high digestibility of $\mathrm{CF}$ $(77.4 \%)$. The OMD of GF was higher than those indicated in Inra tables for forages in early vegetative stage, for which the greatest value is $84 \%$ [2]. This result can be explained by the high WSC content of this forage (table $V I$ ) and also by the high digestibility of fibre fractions (NDF and ADF), which also is according to the low lignification level of the cell wall. These 
latter factors also explain the high net energy content of this forage and the similarity in UFL and UFV values, that is indicative of a high propionate yield during ruminal fermentation [32]. Mean voluntary intake of GF1 was low for a low fibre fresh forage and does not agree with the other observed nutritive parameters. This low intake could be related to the high moisture content of this forage $(87.7 \%)$, since the excess water entrapped in the forage cell structure can produce a physical limitation of intake $[4$, 31]. The higher intake of this material after the maturation process (DL samples), despite its higher cell wall and lignin contents, agrees with this hypothesis. However, the presence of any component that could affect the palatability of the fresh leaves cannot be discarded, since the present work did not include this type of study. Intake of the tested feeds can not be affected by a seasonal effect because the experiments were carried out in the same season (winter). Moreover, the Manchega breed does not present seasonal effects except a lower intake in summer, as consequence of the high temperatures [21].

When the vegetative cycle is finished this material still maintains a high nutritive value. So, when soil contamination was not considered, energy value of DL samples supplemented with urea was similar to that of a medium or good quality hay [2]. Nevertheless, the digestive availability of its $\mathrm{CP}$ results limited, perhaps as a consequence of a high proportion of $\mathrm{N}$-fibre bound (ADIN and NDIN). On the contrary, its voluntary intake is high, similar to that of a fresh grass of good quality [15].

The chemical composition of Cynara cardunculus $\mathrm{S}$ is typical of a fibrous and low protein forage, although with higher contents in CP and lower in fibrous fractions than a cereal straw [2]. The DMD and OMD of this by-product were higher than those indicated for cereal straws supplemented with urea, which are generally below $50 \%[2,16]$. This high level of digestibility can be explained by the lower contents of fibrous fractions of this straw, but also by the higher digestibilities of its cell wall components. Therefore, energy values and intake were higher that those indicated in Inra tables [2] for nitrogen supplemented cereal straws.

\subsection{Rate of passage through the digestive tract and ruminal degradability}

Differences among feeds observed for $k I$ values are in agreement with reports by other authors who suggest that feeds with higher fibre content have lower rumen outflow rates, because they have lower initial densities and more chewing and ruminating needs [20].

Differences observed among feeds for OM effective degradability are in agreement with those detected for OMD. For crop byproducts, the most important difference between DL and $S$ was observed for the undegradable content. So, although ADL content of $S$ was only a bit higher than in DL1, undegradable OM of $S$ was four times higher than in DL1. Lignin effects are not only dependent on its concentration, but also on its distribution in cell wall and vegetable tissues, which can be more or less efficient at preventing microbial attack [11]. In this case, it seems that lignin distribution in $\mathrm{S}$ can prevent microbial attack to more extent than in DL.

Similar rumen degradation of OM and $\mathrm{N}$ observed for GF1 is not common in most forages, and evidence a synchrony in nitrogen and energy-yielding components available for ruminal microbial growth, which may help explain the high digestive utilisation of this material observed in the digestibility trial. Comparison of the $\mathrm{N}$ degradability value with the CP digestibility (CPD, table II) suggests that nitrogenous components are basically digested in the rumen, as occurs in most cases with forages [27]. Degradability of nitrogen was higher than CPD, but this last measure corresponds 
to apparent digestibility, so true digestibility of nitrogen should be higher.

\subsection{Green forage silage}

This forage has some characteristics that could hinder the ensiling process. One is the high buffering capacity, which is higher than those indicated for alfalfa or clover by McDonald et al. [17]. The other is the low DM content, adding to the difficulty of moisture loss during wilting. Thus, the increase in DM content with wilting was very slow with sunny but cold weather conditions and nearly four days were necessary to obtain a DM content of $22.7 \%$. This could be related to morphological characteristics of the plant, which has thick petioles that are difficult to dry. According to Henderson [13], wilting forage until $25-30 \% \mathrm{DM}$ is beneficial for the ensiling process if it is rapid, but if extended over several days soluble carbohydrates will be lost. In spite of this, Cynara cardunculus green forage had a very high content of soluble carbohydrates, which remained unchanged in the forage after $94 \mathrm{~h}$ wilting. This positive characteristic and the good conditions of anaerobiosis resulting from the high density obtained with this forage facilitate the ensiling process. So, fermentative parameters indicate that these silages had undergone a good fermentation, according to the classification of Harrison et al. [12] for grass silages. The high levels in lactic acid of silages - superior than those indicated for grass and maize silages [1] - and its ratios with other acids indicate a lactic homofermentative type fermentation. The imperceptible levels of butyric acid indicate that undesirable microorganisms (clostridia, moulds and yeast) were under control, since butyrate is an endproduct of metabolisation of sugars by these organisms [28]. Silages also showed a low proteolytic activity (according to the moderate contents of ammonia observed), which is another indicator of low activities of undesirable flora, because they also degrade amino acids producing mainly ammonia $[13,28]$. The remaining WSC in ensiled forages was very high, which could be beneficial for the efficiency of microbial protein production if this silage was fed to ruminants $[12,30]$.

The reduction of total losses observed with the wilting period increase agrees with lower fibre contents (NDF and CF) observed for wilted silages than for fresh forage silages. This fact indicates low losses as effluent of soluble materials in wilted silages, which were also associated with higher EDOM values. It is odd that NDF and CF contents of wilted forage silages were somewhat lower than in the original material, but during ensiling, a part of the hemicellulose fraction may disappear [13]. However, losses during the ensiling process are not only due to effluent, but also by fermentation. According to Henderson [13] and Van Vuuren et al. [30], wilting can reduce also fermentation losses, which correlates with the linear increase of $\mathrm{pH}$ and the linear reduction of lactic acid concentration observed with the increase of the wilting period. Thus, wilting tended to moderate the fermentation level, although fermentation was enough to give a correct conservation. These results indicate that wilting was beneficial to reduce effluent losses and to moderate fermentation. However, the difficulty in drying this material makes the use of mechanical treatments during the harvest important in order to accelerate the wilting process.

\section{CONCLUSIONS}

In the vegetative stage, Cynara cardunculus has the characteristics of a very good quality forage with very high digestibility coefficients and, as a consequence, a high energy value. This material is digested mainly in the rumen, with a synchrony in nitrogen and organic matter degradation at this level. In addition, this forage has good ensiling qualities, allowing the wilting of 
the material to reduce the total silage losses and to increase the nutritive value for ruminants. Dry leaves are also of high nutritive value. Supplemented with urea, this material is well consumed and has an organic matter digestibility similar to a medium or good quality hay. Straw of Cynara cardunculus results in a fibrous and low protein forage according to its chemical composition and degradability. However, supplemented with urea, it has higher digestibility and intake than a cereal straw.

\section{ACKNOWLEDGEMENTS}

This work has been supported by the European Union funded Project AIR3-CT93 1089 (Cynara cardunculus Network).

\section{REFERENCES}

(1) Andrieu J.P., Demarquilly C., Caractéristiques fermentaires des ensilages, in: Jarrige R. (Ed.), Alimentation des bovins, ovins \& caprins, Inra, Paris, 1988, pp. 449-453.

[2] Andrieu J., Demarquilly C., Sauvant D., Tables de la valeur nutritive des aliments, in: Jarrige $\mathbf{R}$. (Ed.), Alimentation des bovins, ovins \& caprins, Inra, Paris, 1988, pp. 351-443.

[3] AOAC, Official Methods of Analysis (14th ed.), Association of Official Analytical Chemists, Arlington, VA, 1984.

[4] Demment M.W., Peyraud J.L., Laca, E.A., Herbage intake at grazing: a modelling approach, in: Journet M., Grenet E., Farce M.H., Theriez M., Demarquilly C. (Eds.), Recent developments in the nutrition of herbivores, Proc. of the IVth International Symposium on the Nutrition of Herbivores, Inra, Paris, 1995, pp. 121-141.

[5] Dhanoa M.S., Siddons R.C., France J., Gale L., A multicompartimental model to describe marker excretion patterns in ruminant faeces, Br. J. Nutr. 53 (1985) 663-671.

[6] Ellis W.C., Beever K.C., Methods for binding rare earths to specific feed particles, in: Kennedy C.P.M. (Ed.), Techniques in particle size analysis of feed and digesta in ruminants, J. Canad. Soc. Anim. Sci., 1984, pp. 154-165.

[7] Fernández J., Cultivos energéticos para la Península Ibérica, in: Agrícola Española (Ed.), Los cultivos no alimentarios como alternativas al abandono de tierras, Madrid, Serie Técnica ${ }^{\circ} 8$, 1994, pp. 29-44.
[8] Fernández J., Manzanares P., Cynara cardunculus L., a new crop for oil, paper pulp and energy, in: Biomass for Energy and Industry, 5th EC Conference I, Elsevier, 1990, pp. 1184-1189.

[9] Fernández J., Hidalgo M., del Monte J.P., Curt M.D., Aprovechamiento del cardo (Cynara cardunculus L.) para la producción de biomasa lignocelulósica, aceite y forraje verde, Información Técnica Económica Agraria, Suppl. 17 (1996) 49-56.

[10] González J., Rodríguez C.A., Andrés S.G., Alvir M.R., Rumen degradability and microbial contamination of fish meal and meat meal measured by the in situ technique, Anim. Feed Sci. Technol. 73 (1998) 71-84.

[11] Grenet E., Demarquilly C., Rappels sur la digestion des fourrages dans le rumen (parois) et ses conséquences, in : Demarquilly C. (Ed.), Les fourrages secs : récolte, traitement, utilisation, Inra, Paris, 1987, pp. 141-162.

[12] Harrison J.H., Blauwiekel R., Stokes M.R., Fermentation and utilization of grass silage, J. Dairy Sci. 77 (1994) 3209-3235.

[13] Henderson N., Silage additives, Anim. Feed Sci. Technol. 29 (1993) 113-129.

[14] Hoffman W.S., A rapid photoelectric method for the determination of glucose in blood and urine, J. Biol. Chem. 120 (1937) 51-55.

[15] Jarrige R., Demarquilly C., Dulphy J.P., Hoden A., Robelin J., Beranger C., Geay Y., Journet M., Matterre C., Micol D., Petit M., The Inra "fill unit" system for predicting the voluntary intake of forage-based diets in ruminants: a review, J. Anim. Sci. 63 (1986) 1737-1758.

[16] Kraiem K., Abduli H., Goodrich R.D., Comparison of the effects of urea and ammonia treatments of wheat straw on intake, digestibility and performance of sheep, Livest. Prod. Sci. 29 (1991) $311-321$.

[17] McDonald P., Edwards R.A., Greenhalgh J.F.D., Nutrición Animal, Acribia, Zaragoza, 1988.

[18] Ørskov E.R., McDonald I., The estimation of protein degradability in the rumen from incubation measurements weighted according to rate of passage, J. Agric. Sci. Camb. 92 (1979) 499-503.

[19] Playne M.J., McDonald P., The buffering constituents of herbage and of silage, J. Sci. Food Agric. 17 (1966) 264-268.

[20] Poncet C., The outflow of particles from the reticulo-rumen, in: Jouany J.P. (Ed.), Rumen microbial metabolism and ruminant digestion, Inra, Paris, 1991, pp. 297-322.

[21] Prió P., Plassot L., Gasa J., Caja G., Seasonal hay intake in sheep: effects of environmental temperature and its variations, Ann. Zootech. 43 (Suppl. 1) (1994) 38s-39s.

[22] Ralston M.L., Jennrich R.I., DUD, a derivativefree algorithm for nonlinear least squares, Technom. 20 (1978) 7-14. 
[23] Riveros E., Argamentería A., Métodos enzimáticos de la predicción de la digestibilidad in vivo de la materia orgánica de forrajes, Avances en Producción Animal 12 (1987) 49-75.

[24] Robertson J.B., Van Soest P.J., The detergent system of analysis and its application to human foods, in: James W.P.T., Theander O., Dekker M. (Eds.), The analysis of dietary fiber in food, N Y, 1981, pp. 123-158.

[25] Romero M.J., Otal J., Lorenzo I., Pére $z$ J.I., Utilización del cardo (Cynara cardunculus) como forraje de invierno en ganado ovino. Composición química y digestibilidad in vivo, Información Técnica Económica Agraria, Suppl. 18 (1997) 46-48.

[26] SAS, SAS/STAT User's Guide. Statistical Analysis Systems Institute Inc.. North Carolina, 1990 pp. $1135-1194$.

[27] Sauvant D., Grenet E., Doreau M., Dégradation chimique des aliments dans le réticulo-rumen: cinétique et importance, in: Jarrige R., Ruckebusch Y., Demarquilly C., Farce M.H., Journet M (Eds.), Nutrition des ruminants domestiques. Ingestion et digestion, Inra, Paris, 1995, pp. 383-406.

[28] Thomas C., Thomas P.C., Factors affecting the nutritive value of grass silages, in: Haresign W..
Cole D.J.A. (Eds.), Recent advances in animal nutrition, Butterworths, London, 1985 , pp. 223-256.

[29] Van Soest P.J., Robertson J.B., Lewis B.A., Methods for dietary fiber, neutral detergent fiber, and nonstarch polysaccharides in relation to animal nutrition, J. Dairy Sci. 74 (1991) 3583-3597.

[30] Van Vuuren A.M., Huhtanen P., Dulphy J.P., Improving the feeding and health value of ensiled forages, in: Journet M., Grenet E., Farce M.H., Thériez M., Demarquilly C. (Eds.), Recent developments in the nutrition of herbivores, Proc. of the IVth International Symposium on the Nutrition of Herbivores. Inra. Paris, 1995, pp. 279-308.

131] Vérité R., Journet M., Influence de la teneur en eau et la déshydratation de l'herbe sur sa valeur alimentaire pour les vaches laitières, Ann. Zootech. 19 (1970) 255-268.

[32] Vermorel M., Nutrition énergétique, in: Jarrige R. (Ed.), Alimentation des bovins, ovins \& caprins, Inra, Paris, 1988, pp. 57-74.

[33] Vermorel M., Coulon J.B., Journet M., Révision du système des unités fourragères (UF), Bull. Tech. CRZV Theix, 70 (1987) 9-18. 